responsible for public health in their respective areas, and for markets, water-supplies, and primary schools; law and order are the responsibility of the local councils. Each type of council is empowered to collect money for the specific purposes lying within its competence.

\title{
Aiyetoro: a pioneer community development project
}

Nigeria, no. 36, I95 I, contains an account of a remarkable community created and built up by a small group of African fishermen without Government, Mission, or other outside assistance of any kind. Aiyetoro (meaning 'the world is at peace') is a town of 2,000 inhabitants, which has been created during the last three years on the sea-shore of Ondo province, Nigeria, and is the scene of a very successful form of communal living. The strip of muddy, open, swamp country, between the beach and the swamp forest, east of Lagos, has for hundreds of years been inhabited by Ilajes, a Yoruba-speaking tribe living in small villages separated by creeks and swamps and making a living by fishing; the nature of the country has not favoured the development of communal activities. In the middle nineteenforties a number of men and women formed a religious society calling themselves the 'Holy Apostles', their object being to break away from the old conditions of living that offered little prospect of change or improvement. In 1947, under the guidance of three outstanding personalities, plans for founding a new community took shape; it was proposed that members should try to follow the teaching of the New Testament, and that every man and woman should work for the community, all profits going into a common purse. A site for a town was selected by the sea, since sea fishing was to be the main industry. The town has been admirably laid out, allowing for expansion as the population increases; causeways have been built of planks raised on stakes three feet above the swamp, and arranged at right angles to the sea coast; houses are made of planks roofed with aluminium, and sited to secure the maximum amount of light and air. Although fishing is the main industry, the community now owns a weaving industry, a tailoring establishment, a carpenter's workshop, a dyeworks, a laundry, a sun-helmet factory, and a town gardener-the aim being to make the community as self-supporting as possible. The administration of the community is carried out by a committee of 16 elders, men and women, and various sub-committees are concerned with the allocation of food, clothing, \&c., and the running of the various industries. There are no private incomes; all sales from fishing, both local and export, are paid into the community purse; all requirements are supplied by the community, which has accumulated funds for capital expenditure, such as electric light. Each day starts with a service in the church, lasting about two hours, after which the industrial life of the community comes into full action. The cleanliness and order of the houses and the town generally, the healthy and happy appearance of the people, their clean, serviceable, and picturesque clothing (uniforms have been devised for fishermen, market women, and other special classes of the population), are noticeable features of the settlement.

The remarkable success of this pioneer effort suggests that similar enterprises organized in agricultural communities might effect much needed improvements in living conditions and help to arrest the drift of populations to the towns.

\section{Copperbelt: Conference on Social Welfare}

A CONFERENCE called by the United Missions in the Copperbelt was held at Mindolo Mission, N. Rhodesia, in May 1950 under the chairmanship of the Rev. G. R. Fraser; the main topic of the conference was family life in relation to social change. Mr. J. D. Rheinallt Jones, in the conference opening paper, indicated the need for assisting the African to adjust himself to the impact of European civilization, and made a strong plea for an adequate demographic survey to furnish accurate information about the movements of peoples, their 